The proto-politics of reconciliation:

Lefort and the aporia of forgiveness in Arendt and Derrida

Andrew Schaap

Department of Political Science

The University of Melbourne

Victoria 3010

aschaap@unimelb.edu.au

Forthcoming in the Australian Journal of Political Science, September 2006. 


\section{The proto-politics of reconciliation:}

\section{Lefort and the aporia of forgiveness in Arendt and Derrida}

Reconciliation is often suspected of being an inherently ideological concept in the sense that it fosters acquiescence to a social order that is neither necessary nor desirable. In particular, it is sometimes argued that this is because reconciliation is a religious concept that has been transposed into political discourse. This transposition is seen to be inappropriate because reconciliation presupposes a prior social unity that needs to be restored when, in fact, no such unity has ever existed between historical antagonists. In this article, I argue that the presupposition of a social unity is, indeed, always in danger of becoming ideological to the extent that this unity is conflated with the nation. However, the invocation a counterfactual social unity or 'polity' also potentially enables the staging of a reconciliatory politics in a way that politicises the terms of association between former antagonists.

It is widely recognised that reconciliation is a theological term, which became prominent in secular political discourse in divided societies around the world at the end of the twentieth century. It is a matter of debate whether the theological baggage that the concept of reconciliation seems to bring to secular politics opens up or impedes democratic deliberation and contestation in such societies. Does the theological-political concept of reconciliation enable a deeper moral-political engagement among a citizenry divided by a history of state violence? Or does it inevitably coopt political challenges to a ruling class by re-presenting these within a nationalist ideology? ${ }^{1}$

I have previously argued that if we are to conceive of reconciliation politically, we should be wary of the religious metaphors on which

\footnotetext{
${ }^{1}$ Earlier versions of this paper were presented at the Derrida Roundtable at the University of Melbourne in February 2005 and at the Philosophy Seminar at University of Queensland in October 2005. I am grateful to participants at both these events for their responses to the paper. Special thanks to Keith Breen, Marguerite La Caze, Emma Larking, Hans Lindahl and one anonymous reviewer for their detailed and thoughtful comments on the paper.
} 
reconciliation processes often rely (Schaap 2005, 13-22). The danger of the religious metaphor of redemption when applied to the nation (together with the economic metaphor of settling accounts and the therapeutic metaphor of healing) is that it tends to depoliticise the terms in which a reconciliatory politics might be enacted by presupposing the very political unity that is at stake. By engaging with the work of Claude Lefort and Bert van Roermund, however, I have come to understand, that the religious dimension of the concept of reconciliation - its reference to a counterfactual community that transcends present political circumstances - is fundamental to the politics of reconciliation.

In this article, I seek to develop this understanding in dialogue with Michael Phillips' (2005) recent article in AJPS on the 'religious politics' of reconciliation in Australia. Building on Phillips' analysis, I argue that the religious dimension of reconciliation is manifest in its reference to the quasitranscendent figure of 'the people': the "we" that is unavoidably invoked to enable and to authorise the collective act of reconciling. I refer to this as the proto-politics of reconciliation in the title of this article. This term is meant to encapsulate the idea that reconciliation necessarily invokes both an original unity that has never actually existed and an ultimate unity that remains to come in order make politics possible in the present.

Drawing on Lefort, I describe this reference to a quasi-transcendent unity in terms of the distinction between politics as a vocation and the invocation of polity. I then go on to discuss the retrospective and prospective invocations of polity in the politics of reconciliation in terms of protology and eschatology: the origin and end of reconciliation. I conclude by examining Derrida's and Arendt's thoughts on the place of forgiveness in politics in terms of the politics/polity distinction and their contrasting conceptions of polity: the eschatological dimension of Derrida's democracy to come and the protology Arendt presents in The Human Condition.

The upshot of this analysis is a qualification of my earlier suspicion of the religious dimension of reconciliation: while the presupposition of a social unity on which a reconciliatory politics depends is always in danger of becoming ideological it is not necessarily so; the invocation of polity (both in its 
protological and eschatological forms) can also serve to politicise the historical terms of political association by revealing how the relation between colonisers and colonised might otherwise be.

\section{Politics as a vocation and the invocation of polity}

The politics of reconciliation characteristically turns around the representation of the good polity, of what kind of reconciled society "we" should strive toward and what it would take to achieve it. As such, the politics of reconciliation (as, indeed, all politics) necessarily relies on the invocation of a "we", which even 'sober and practical people with a preference for results rather than metaphysics' (Phillips 2005, 111) must claim to represent. To invoke is 'to call upon, to call to (a person) to come or to do something' (OED). In another, closely connected sense, it means 'to appeal to, cite or posit in support of a course of action, explanation, etc.' (OED). Those who would initiate political reconciliation must invoke 'the people' in both senses of 'calling upon' and 'positing' a social unity. The notion of invoking is often associated with conjuring spirits or ancestors in traditional societies. Yet, it is similarly apposite to talk about invoking 'the people' in modern secular societies, given the irrepresentability of the first-person plural on whose will the legitimacy of law and policy in a democracy depends.

Michael Phillips provides two citations, which highlight what Emilios Christodoulidis (2000: 190f.) refers to as the 'embarrassment of the first person plural' in the politics of reconciliation: the difficulty of invoking a "we" in terms of which conflicting narratives of the past might be represented.

... above everything else we are united together as Australians, living under one body of law, that to which we are equally accountable but from which we are entitled to an equal dispensation of justice. Now that is how I see...the reconciliation process. (John Howard, Australian Prime Minister, 1996-, cited by Phillips 2005, 121 - emphasis added)

We are here. Stop the denial...What are we if we're not separate peoples? (Geoff Clark, Chairman of the Aboriginal and Torres 
Strait Islander Commission (ATSIC), 1999-2003, cited by Phillips

2005, 121 - emphasis added)

"What are we if we're not separate peoples?" The ambiguity of Clark's question points to the contestability of the "we" in terms of which a politics of reconciliation is enacted. Does Clark mean 'What are we [indigenous people] if we [Australians] are not separate peoples?' Or rather, 'What are we [Australians] if we [indigenous and non-indigenous Australians] are not separate peoples?'

The first interpretation points to the risk that reconciliation turns out to be an ideological concept that legitimates further assimilation by the colonising "we", which excluded the colonised from the original social contract. ${ }^{2}$ If "we Australians" are united as one people, on whose terms might indigenous peoples be recognised as having a distinct status within that political unity as first nations and traditional owners of the land? The second interpretation points to the ongoing legitimation crisis of the post-colonial state: its inability to recognise indigenous sovereignty in retrospect without thereby forfeiting its own claim to legitimacy ('one body of law' referred to by Howard) and hence its right to decide that question in the first place (see Kerruish \& Purdy, 1998; Patton, 2000: 30-34). ${ }^{3}$ If "we Australians" are separate peoples, then on what grounds does the Australian State's claim to represent the wills of both peoples rest?

These conflicting interpretations draw attention, respectively, to the risk that the theological dimension of reconciliation brings to political discourse and to the opportunity that it affords: it can serve either to frustrate or facilitate the expression of political claims aimed at redressing those injustices on

\footnotetext{
${ }^{2}$ As Paul Patton $(2001,25)$ notes, 'Australia is unique among former British colonies in never having signed treaties with its indigenous peoples and the present Constitution was formulated exclusively by representatives of the European population without consultation with Australian indigenous peoples. In its 1901 version, the constitution explicitly denied the Commonwealth power to make laws regarding 'Aboriginal natives' and excluded them from being counted in the census. While these exclusions were removed by referendum in 1967, other remnants of early $20^{\text {th }}$ century racism remain in the document...Section 25 which envisages a situation in which 'certain races are disqualified from voting' remains intact.' ${ }^{3}$ As Patton $(2001,32)$ points out, 'if the abandonment of extended terra nullius in international law supports the case for the Australian recognition of native title, it is difficult to see why the recognition of native title does not in turn threaten the legitimacy of the British claim to sovereignty.'
} 
which a state is founded. Or, as Michael Phillips $(2005,112)$ puts it, it might limit or legitimise Indigenous claims to reparative, distributive and/or constitutional justice. On the one hand, the positing of a unity over-determines the terms on which legitimate politics might be enacted and thereby coopts political conflict into restoring the good conscience of the nation (cf. Moran 1998; Short 2005). ${ }^{4}$ On the other hand, the reference to an ideal community that is the 'other' of the nation provides a counterfactual in terms of which the historical terms of political association between the settler and indigenous societies might be imagined otherwise (cf. Muldoon 2003: 187f.). ${ }^{5}$

Despite a preference for 'practical reconciliation' by many of those for whom politics is a vocation, individuals such as John Howard and Geoff Clark cannot act in their representative role without invoking polity. This necessarily brings a religious or quasi-transcendental dimension to politics. The risk that the theological element might become ideological cannot be avoided by disclaiming all metaphysical presuppositions since this only leaves us inarticulate about how we imagine political society in the first place. Rather, the challenge is to invoke polity in a way that enables the representation of social conflict without over-determining the terms in which it might be worked (or played) out.

\section{Reconciliation and the staging of politics}

In his recent article in AJPS, Michael Phillips (2005) helps to clarify the debate about the appropriateness of employing a theological concept such as reconciliation as a policy frame within a secular state such as Australia. He does so by distinguishing between three conceptions of secularisation in terms of which we might understand the relation between the political and the theological. In its first, Lockean sense, secularism is a political doctrine predicated on the separation of Church and State and the differentiation of the legitimate scope of the authority of each in relation to their respective ends:

\footnotetext{
${ }^{4}$ I.e. by invoking 'a nation in which various sub-national groups had given up their special claims and historical grievances in the interest of a common, united future' (Phillips 2005, 120).

${ }^{5}$ Reconciliation would invoke 'not the dissolution of difference' but a 'unity in which division, rather than difference, was transcended' (Phillips 2005, 122).
} 
salvation (a matter of private faith) and security (a matter of public reason). The legitimacy of the sovereign's right to rule is no longer justified by appeal to a higher law that the Prince claims to represent. Rather, it rests on the (tacit) consent of each individual to abide by the institutions in which they have a reciprocal interest, the satisfaction or violation of which can be judged by recourse to public reason.

In these terms, reconciliation is an inappropriate term of political discourse insofar as it is predicated on a substantive conception of the good. For instance, Gutmann and Thompson (2000, 29-33) argue that a 'thick' conception of reconciliation, which presupposes that forgiveness is integral to the politics of reconciliation, presupposes a comprehensive moral doctrine that is not shared by all members of society and therefore cannot be the object of an overlapping consensus arrived at through the use of public reason. Rather than social harmony, they argue, we should understand reconciliation in terms of democratic reciprocity. The principles by which we organise society should be limited to those to which all reasonable members of society might agree. ${ }^{6}$

The problem with trying to understand political society in such instrumental terms is that it cannot account for how those who would enter into a social contract might come to think of themselves as a "we" in the first place. ${ }^{7}$ While each might recognise his or her private interest in securing life, liberty and property, this kind of secular society cannot account for why each should look to shared public institutions to do this. This problem is particularly acute where the parties to the contract are not in a hypothetical state of nature or original position but a relation of oppression: a situation in which unjust social relations have been legitimated by the same institutions that are supposed to regulate their coexistence now and in the future (Van Roermund 2001: 187f.; Schaap 2005, 31-39).

In its second, Kantian sense, secularism describes the process of disenchantment in modernity. On this account, secularism is associated with the decline in religion and increasing rationalisation of society. In its optimistic

\footnotetext{
${ }^{6}$ For a critique of Gutmann and Thompson see Schaap (forthcoming).

${ }^{7}$ This is Kant's critique of the Hobbesian social contract. See Habermas (1996, 90-94).
} 
rendering this means progressive enlightenment. ${ }^{8} \mathrm{~A}$ common objection to framing public-political discourse in a democracy in terms of reconciliation, which presupposes this conception of secularism, is that it 'frustrates the modernist project of building a perfectly rational public sphere' (Phillips 2005, 114). This critique underlies concern that talk of guilt and forgiveness in politics is a distraction from the social justice issues that are really at stake in relations between indigenous peoples and the settler society and can be addressed by practical remedies. Moreover, it suggests that talk of reconciliation can only serve to mystify the bases of collective solidarity in a complex society because it appeals to an image of the people as family or organic community, the harmony of which needs to be restored. ${ }^{9}$

Despite its apparent plausibility, I agree with Phillips that this objection is (at least partially) misplaced for reasons that become clear in terms of the third, Schmittian view of secularisation that he favours (Phillips 2005: 115). On this account 'secularisation is not the rationalisation of the world to the exclusion of the sacred, but the secularisation of theological concepts themselves, such that they are no longer thought to make sense only in connection with the divine' (Phillips 2005, 115). Secularisation is the transposition of theological concepts to political discourse. This conception of secularisation implies that it is a mistake to view secular society as grounded entirely on principles that are political not metaphysical since this only blinds us to our metaphysical presuppositions. As Schmitt (1985) himself writes, the 'metaphysical image that a definite epoch forges of the world has the same structure as what the world immediately understands to be appropriate as a form of its political structure' (cited by Phillips 2005, 115). For Schmitt, the

\footnotetext{
${ }^{8}$ On the pessimistic view, not discussed here, the world comes to be interpreted in terms of use-value rather than its intrinsic worth so that human existence appears increasingly meaningless and the bases of social solidarity are eroded (e.g. Weber, Maclntyre).

${ }^{9}$ Cf. Chilean intellectual Tomás Moulian (cited in Atria, forthcoming): 'There won't be any reconciliation. In the first place, reconciliation is a bad word. Reconciliation is brotherhood. That is to say, it is for two brothers that were separated by some conflict, but recognise the fact that they share the same history and the same blood. Pinochetists and anti-Pinochetists, however, don't share the same blood. Reconciliation is a fake subject. Granted, we have to learn to tolerate each other, but I have no reason why I should love the torturer. No. It is simply a mystic delusion. It is a concept from theological discourse that has been displaced to political discourse. We can say that we need to be able to live in peace, for ethical and practical reasons, so that there won't be any more killing. I am not the son of a disappeared, but I am not reconciling with those who killed or tortured them. No, I am not reconciling.'
} 
secularisation of political society is a process whereby the transcendent authority of God becomes immanent in 'the people'.

It is at this point that Claude Lefort's notion of the 'staging' of politics, his distinction between politics and the political and his account of democracy as a regime in which the locus of power is an empty place can serve to further elucidate and elaborate Phillips' analysis. Against Schmitt's understanding of the meaning of democracy as the identity of rulers and ruled, Lefort argues that the figure of 'the people' remains a quasi-transcendent source of authority within a democracy because it is irrepresentable. ${ }^{10}$ In preserving the distance between the rulers and ruled or, rather, 'the people' and its representatives, Lefort preserves a space for politics within the political association: the ceaseless contest over the representation of the political community to itself. Political society cannot perceive itself as a whole without reference to an imagined time and space that transcends society in terms of which it might regard itself: this is what invocation of the "we" performs.

If what is fundamentally at stake in the politics of reconciliation is the extent to which Indigenous justice claims are limited or legitimised, this draws attention to the fact that politics always ultimately turns around the terms in which social conflict is represented. ${ }^{11}$ Yet any political articulation of the general interest must necessarily refer beyond the particular context within which it is invoked to an imagined unity in terms of which this society can represent itself to its members. Lefort $(1988,219)$ refers to this as the 'staging' of social relations - the representation of social division or conflict in relation to an idea of unity that is not reducible to any determinate political community.

In this context, Lefort $(1988,217)$ distinguishes politics from 'the political' or what I prefer to call 'polity' (see also Ricoeur 1965; Dallmayr 1993a). Whereas politics refers to social conflicts among competing interests and values, polity or 'the political' refers to the 'principles that generate society'

\footnotetext{
${ }^{10}$ I am indebted to Hans Lindahl for drawing my attention to this fundamental difference between Schmitt and Lefort.

${ }^{11}$ As Gillian Rose (1996: 4) points out, 'Politics begins not when you organise to defend an individual or particular or local interest, but when you organise to further the 'general' interest within which your particular interest may be represented.'
} 
and in terms of which politics is staged. On this account, society cannot be understood in terms of 'politics' alone: for social division only becomes meaningful to the extent that it is represented as an internal division. The reality of social conflict thus makes sense only against the background of some idea of social unity. ${ }^{12}$

Democracy can be differentiated from other types of regimes, in this context, according to the principles in terms of which politics is staged. Lefort (1988: 16) describes democracy as a 'society, which, in its very form, welcomes and preserves indeterminacy. ${ }^{13}$ In a monarchy, power is embodied in the prince who mediates between the transcendent (God, reason or natural law) and the mundane. As such, the authority of the Prince is modelled on the figure of Christ, the incarnation of the divine. The representation of power takes the form of embodiment. In contrast, in democracy power is disincorporated so that the 'locus of power is an empty place, it cannot be occupied... and it cannot be represented' (Lefort 1988: 17). ${ }^{14}$

With secularisation, sovereignty is transferred from the Prince to a 'people', which is understood to give itself its own laws. Yet this sovereignty cannot be represented in the body of a sovereign. For, were the people to delegate their sovereignty, they would forfeit their democratic freedom to be self-determining since, in Rousseau's [1762] terms, 'the People subject to the laws ought to be their author' (II.6.10; see also II.7.7; III.1.3). On the other hand, however, there is no such 'thing' as the people to represent in the first place. The invocation of the people serves only 'to present a bunch of different, partially even conflicting interests as a unity' (Van Roermund 1996:

\footnotetext{
${ }^{12}$ As Lefort (1988: 218) puts it, 'social division can only be defined...insofar as its terms are determined by relations, but also insofar as those relations are themselves determined by their common inscription within the same space and testify to a common awareness of their inscription therein.'

${ }^{13}$ In a much cited passage, Lefort $(1988,19)$ continues, 'democracy is instituted and sustained by the dissolution of the markers of certainty. It inaugurates a history in which people experience a fundamental indeterminacy as to the basis of power, law and knowledge, and as to the basis of relations between self and other, at every level of social life (at every level where division, and especially the division between those who held power and those who were subject to them, could once be articulated as a result of a belief in the nature of things or in a supernatural principle)' (emphasis in original).

${ }^{14}$ As Bernard Flynn (1998: 489) explains, in a democracy, 'there is no one who is a priori certified to speak in the name of the people. Each one does speak in the name of the people, but each is legitimately contradicted by others who, with as much right, also evoke the name of the people'
} 
33). It does not correspond to an actually existing entity capable of expressing its will. For, as Lefort observes, at the moment in which the people is supposed to speak directly (e.g. in a general election) it dissolves into an aggregate of individual wills (i.e. votes). ${ }^{15}$

This central term of modern political discourse thus brings to light the relation between politics as a vocation (empirical conflicts of interest and value within society) and the invocation of polity (a quasi-transcendent unity that is required in order to render such conflicts meaningful and hence, at least potentially, amenable to resolution). What distinguishes a democracy from other regimes (such as monarchy or totalitarianism) is that in a democracy, power is kept in view for being symbolic rather than real. As Bert van Roermund $(1996,42)$ explains:

In a democracy, the symbolic character of the exterior place of power is acknowledged, not in the sense that it is constantly disguised as a fiction, but in the sense that this place is preserved in its constitutive function of making social life possible, since imaginable, interpretable, corrigible and organisable, but always up to a certain point, and never to the end of a definitive truth.

In contrast, the policies of extermination, segregation and assimilation enacted by the settler society and its state against indigenous peoples can be understood in relation to the anti-democratic aspiration to materialise the symbolic by 'incorporating' power in a determinate historical community: White Australia.

The possibility of coming to terms with this legacy - the problem of reconciliation in Australia - in this way coincides with the problem of democratic representation described by van Roermund (1996, 34): 'to imagine a political self without there being a subject which this self reflects.' The legacy of state violence cannot be addressed by simply abandoning the idea

\footnotetext{
15 'The people possesses sovereignty; they are assumed to express its will; power is exercised in their name; politicians constantly evoke them. But the identity of the people remains latent. Quite apart from the fact that the notion of the people is dependent upon a discourse which names the people, which is itself multiple and which lends the people multiple dimensions, and that the status of a Subject can only be defined in terms of a juridical constitution, the people are, as we have noted, dissolved into a numerical element at the very moment of the manifestation of their will' (Lefort 1988: 230).
} 
of 'the people' on the basis that it does not really exist for this would only leave us inarticulate about the idea of unity that is presupposed. Rather, the problem is how to invoke polity without hypostatising it so that it becomes ideological (cf. Norval 1998).

\section{The origin and end of reconciliation}

Michael Phillips argues that reconciliation exemplifies a religious concept that has been transposed into secular political discourse. 'When we talk of reconciliation as a political program somehow apart from the perennial business of reaching compromise or establishing a modus vivendi between competing groups we move, more often than not, into the realm of theology' (Phillips 2005, 112). In Lefort's terms, a politics of reconciliation moves toward the theological to the extent that it invokes polity: a social unity that transcends this determinate political community and in terms of which social division might be represented.

This becomes clear when we consider a further common objection to the secularisation of reconciliation, which Phillips does not mention: the 're' in reconciliation refers to a return, to the restoration of friendship or harmony following the rupture of relationship by some wrongdoing. Yet, in this restorative sense, reconciliation appears poorly suited for understanding how to address the legacy of colonisation and oppression, the legitimation of state violence perpetrated by one population against another in the name of the people. As such, reconciliation seems to require the 'restoration of an original harmony that...has never existed between indigenous and non-indigenous Australians' (Diprose 2002, 148 cited in La Caze forthcoming). ${ }^{16}$

As theological concept, reconciliation refers not only to an eschatology (a final end, the hope for salvation) but a protology (a story of the original condition of humanity). In Christianity reconciliation presupposes a 'prelapsarian state' of harmony prior to humanity's alienation from God and enmity among men (see Moon 2004, 193f.; Atria, forthcoming). The

\footnotetext{
${ }^{16}$ In relation to South Africa, Antjie Krog $(1998,109)$ similarly observes that 'there is nothing to go back to, no previous state or relationship one would wish to restore.'
} 
community it seeks to restore is thus not the determinate political community of a nation but the unlimited moral community of humanity. As political concept, however, reconciliation characteristically takes the nation as its reference point. It is in this context, that the Kantian critique of reconciliation gains its plausibility: reconciliation becomes ideological to the extent that it conflates the political community with the moral community; it depoliticises unjust social relations by representing them as constitutive of a 'good people' (e.g. see Moran 1998).

On the other hand, the invocation of a prelapsarian state also opens up political opportunity: in Lefort's terms, the imagination of a time and space beyond empirical time and space provides a context in terms of which social conflict can be staged in a way that establishes the possibility of talking about this conflict as one internal to a society (a struggle for recognition) and thus potentially amenable to a principled resolution rather than one between enemies (continuation of war by other means) to be settled ultimately by force. In other words, it is precisely because there is nothing to go back to in historical terms that the 're' in reconciliation is important; the reference to a prelapsarian state enables us to imagine how the relation between coloniser and colonised might otherwise be. ${ }^{17}$

The extent to which a politics of reconciliation leads to the democratisation of relations between colonisers and colonised or becomes an ideological discourse that further assimilates indigenous people into the Australian nation thus depends on the extent to which the "we" that is invoked in order to enable this politics is kept in view for being contestable or whether it is hypostatised. In Lefort's terms, it is not the reference to the theological per

\footnotetext{
${ }^{17}$ Claire Moon discusses these two interpretations according to whether we construe the theological element of reconciliation in terms of narrative or metaphor. As narrative, reconciliation seems to over-determine the terms in which politics can be enacted because it scripts what reconciliation requires too tightly; since it 'prefigures narrative closure as reconciliation' it tends to privilege a certain conception of social unity as a regulative idea in terms of which all conflict is interpreted (Moon 2004, 194). As such, the transposition of religious discourses into secular politics can 'work against constituting different political configurations and alliances' since they tend to 'reify the national boundaries of community and the contractual relations adjudicated by the state, and to re-establish the boundaries of the existing legal order' (Moon 2004, 1997). In contrast, when read as metaphor, the transposition of reconciliation to the secular domain extends the debate about dealing with the legacy of oppression 'beyond the idea of a pragmatic settlement or agreement' while at the same time generating 'debate and contestation about what reconciliation might mean' (Moon 2004, 195).
} 
se that makes reconciliation potentially ideological but rather the way in which the idea of social unity (in terms of which all politics is inevitably represented) is conceived. In a democracy, 'society is instituted as a society without a body' rather than an 'organic totality' (Lefort 1988, 18). This is not to say that society has no unity or identity. Rather, the people, the nation and the state 'take on the status of universal entities' but these are kept in view for being insubstantial and therefore dependent upon political discourse and contestation for their articulation.

Lefort notes that in human affairs, unity has 'always been conceived beneath the sign of the spiritual' while division is 'projected on to the material plane of interest' (Lefort 1988, 230). Yet we can no more make sense of material conflicts of interests independently of our ideas of social unity than our ideas of social unity could make sense in isolation from our experience of division:

What philosophy discovers in religion is a mode of portraying or dramatising the relations that human beings establish with something that goes beyond empirical time and space within which they establish relations with each other. This work of the imagination stages a different time, a different space.

(Lefort 1988, 223)

Political philosophy necessarily relies on the religious imagination, therefore, insofar as it refers to a 'time that exists outside time' (i.e. a counterfactual image of human sociality prior to the institution of law) in order to understand and criticise (or justify) existing social relations (Lefort 1988, 232). The state of nature, in its various imaginings, is the best-known philosophical representation of a protology. As Phillips $(2005,116)$ observes, Marx and Engels' 'classless society', in which the state withers away, is a good example of a political eschatology.

In the remainder of this paper I draw out the affinities and differences between Arendt's protological and Derrida's eschatological conceptions of polity in order to better understand their apparently competing accounts of the place of forgiveness in politics. My purpose in doing so is to gain some further 
insight into how the proto-political or quasi-transcendental referent of reconciliation (its origin and end) might inflect ordinary politics.

\section{The aporia of forgiveness}

Reconciliation is often promoted in the context of transitional justice in which a new democratic regime must reckon with the legacy of human rights violations perpetrated by its predecessor. In such situations, the project of reconciliation sanctioned by the state and the international community is intended to legitimate the successor regime as it balances the retrospective demands of corrective justice (e.g. criminal prosecutions, reparations, repatriation and lustration) with the prospective demands of constituting and consolidating a liberal-democratic political order. In Australia, we have not witnessed a dramatic regime change such as in South Africa or Chile. However, reconciliation was similarly associated with an effort to confront wrongs against indigenous people, which were either perpetrated or sanctioned by the state, in order to draw a bright line under the colonial past and establish a new post-colonial relation between settler and indigenous societies.

In such situations, as Phillips $(2005,119)$ observes, the 'transformative potential of reconciliation politics derives from its seeming ability to transcend the exacting requirements of perfect justice'. But this raises the question, how might a reconciliatory politics transcend justice without becoming complicit in injustice? If political reconciliation does require sacrificing justice for the sake of social stability then why not recognise it for what it is - a modus vivendi based on a strategic compromise - rather than trying to pass it off as the restoration/transformation of moral-political community?

What Phillips calls the aporia of justice and forgiveness is not simply a practical difficulty that confronts divided societies struggling to deal with the legacy of political violence; it is a conceptual difficulty that can be expressed in terms of a logical paradox. Derrida $(2001,32-33)$ describes this aporia when he says that 'forgiveness forgives only the unforgivable'. But the paradox is perhaps more clearly expressed by Aurel Kolnai $(1977,217)$ when he says that forgiveness seems to tend either toward redundancy or condonation in its 
relation to (in)justice (cf. Murphy 1988, 167f.). If forgiveness is 'conditional' then it risks being superfluous: forgiveness becomes redundant when reserved only for those who deserve it (because they have recognised their wrongdoing, expressed remorse, tried to repair the harm and reaffirm the norm that has been violated). If in relinquishing our justified resentment for the wrong inflicted on us we are only giving our transgressor what is due to him or her as a co-member of the moral community, what need has the wrongdoer of our forgiveness? Since it would be unjust to maintain a resentful attitude towards someone who deserves to be forgiven, it hardly seems appropriate to speak of forgiveness at all. The concept of justice will be sufficient on its own.

On the other hand, if forgiveness is 'unconditional' or supererogative, it risks being unjustified. To forgive an undeserving (because unrepentant or unapologetic) wrongdoer seems actually to condone the wrong by not holding the other to account in terms of the norm that has been violated. Forgiveness makes possible a relationship between us but only by suspending those norms that ought to regulate our coexistence in the first place. When understood as a freely given-gift, forgiveness appears incompatible with justice because of its arbitrary nature. It 'transcends' justice because it is a matter of will and decision rather than reason and judgement. The undeserving wrongdoer has no moral or political claim to our forgiveness; it is ours to give or withhold as we see fit. It is a gift ventured freely out of concern for this particular person. As responsiveness to a singular other, it is unavoidably partial since it forgoes the procedural requirement to treat like cases alike.

According to Derrida (2001, 35), it is due to these two competing conceptions of forgiveness (as unconditional/gracious in contrast to conditional/normative) that the injunction to forgive is 'at once double and contradictory.' As Phillips $(2001,120)$ observes, the aporia of forgiveness that Derrida describes at the conceptual level, re-emerges in the politics of reconciliation, which requires that 'injustice is both affirmed [i.e. recognised] and transcended.' Reconciliation cannot be based on forgetting the past; it is only possible by acknowledging those injustices against indigenous people in which all members of the settler society are implicated. Yet, it also requires 
acknowledging the irreparable nature of those wrongs (see Perrin \& Veitch 1998). Reparations are one way of recognising past injustice but they cannot be sufficient to satisfy the demands of justice. If political community is to be possible between indigenous and settler Australians, reconciliation will thus also require 'transcending' justice. But the question returns of how this is possible without reconciliation becoming an ideological discourse that silences further indigenous justice claims by enacting an unwarranted closure.

Bert van Roermund $(2001,2004)$ offers an insightful account of how a politics of reconciliation might both recognise past injustice and transcend the demands of justice when he distinguishes between two orders of reconciliation, which he calls the practical and the anthropological sequences. The practical order is the one more familiar to us because it is associated with conditional forgiveness: a perpetrator alienates himself from the moral community in doing wrong, the way back depends on a shared acknowledgement of the nature of the wrong and the norm that was violated, followed by remorse, repentance, reparation, etc. by the perpetrator which open the way for forgiveness by the victim and, finally, reconciliation. As van Roermund notes, this is often a reasonable way of doing things but it cannot account for the transformative aspect of reconciliation. This requires attention to a second sequence, which he calls anthropological: it is a willingness to forgive on the part of the victims that opens the way for the perpetrators to assume responsibility by agreeing to honour it as a history of 'right suffering'. Van Roermund (2004) appropriately names the kind of 'responsive remembrance' that reconciliation mobilises, 'anamnesis' - a mode of remembering which promises to honour the victims by giving them 'a dignifying past, a past to look forward to.' The part of Van Roermund's (2001, 179) detailed analysis that interests us here is his observation that, in the anthropological sequence, contrary to our normative expectations, the revelation of truth is not a precondition for reconciliation but rather 'reconciliation is what makes the revelation of truth possible' (see also Schaap 2005, 77-85).

In terms of our discussion of the proto-politics of reconciliation we might say that in the case of the practical sequence, forgiveness is enacted in 
politics against the background of an already instituted order of legitimate expectations (norms). In the case of the anthropological sequence, in contrast, forgiveness is associated with a conception of polity that transcends any existing normative order but in terms of which politics might be staged. In the anthropological sequence, the invocation of a we that is willing to forgive is what makes politics possible in the first place.

Significantly, however, although it suggests an account of how a reconciliatory politics might transcend justice without becoming unjust, Van Roermund does not call this second sequence theological but anthropological. This is because he understands political anthropology to be consonant with a protology (an account of an original state of human coexistence prior to the establishment of institutions) in contrast to an eschatological account of forgiveness as a hopeful horizon in terms of which a redeeming memory might be possible. The idea of an unconditional forgiveness that could be offered only by a divinity means that human existence remains always redeemable no matter what depth of fault we might sink to. Against this vertical dimension (between the height of forgiveness (God) and the depth of fault (humans)), van Roermund draws attention back to the horizontal dimension of reconciliation among women and men, which he describes in terms of a protology. ${ }^{18}$

\section{Forgiveness and polity}

Derrida's and Arendt's contrasting accounts of the place of forgiveness in politics might fruitfully be compared in terms of these contrasting ways of thematising polity: as eschatology and protology. ${ }^{19}$ It is because 'pure'

\footnotetext{
18 'Forgiving is perhaps as much about acquiring a shared remembrance of the violent past as it is about internalising the height of the moral point of view, form which 'the unforgivable can be forgiven'. In any case, we should not understand this formula...in such a way that the unforgivable becomes forgivable after all, by internalising a higher point of view. The only way, I submit, in which the unforgivable can be forgiven is by remembering it as 'common', i.e. by appreciating the horizontal rather than the vertical dimension of reconciliation...there is a protology of remembrance, which is as essential as Ricouer's eschatology' (Roermund 2004).

${ }^{19}$ I have benefited from reading Michael Janover's (2005) careful comparison of Arendt's and Derrida's thoughts on forgiveness and politics in preparing this section of the paper. For thoughtful commentaries on Derrida's work on forgiveness in the context of debates about reconciliation see also Verdeja (2004), Moon (2004) and La Caze (forthcoming).
} 
forgiveness cannot and should not be normative but must remain exceptional that Derrida (2001, 31-32, 39) insists forgiveness 'remains heterogenous to the order of politics or of the juridical as they are ordinarily understood'. Paul Ricoeur $(2004,488)$ similarly asserts that 'there is no politics of forgiveness' citing the 'sometimes monstrous failure of all efforts to institutionalise forgiveness' as evidence for this. By insisting on the non-political character of forgiveness, Derrida and Ricoeur both take issue with Hannah Arendt who views forgiveness as an inherently political response to wrongdoing. According to Arendt $(1998,246)$, forgiveness and promising 'are the only moral precepts that are not applied to action from the outside, from some supposedly higher faculty or from experiences outside action's own reach. They arise, on the contrary, directly out of the will to live together with others in the mode of acting and speaking.'

Derrida's insistence that forgiveness exceeds politics 'as it is ordinarily understood' depends on his association of politics with the sovereignty of a juridical or normative order. In this context, there are at least three reasons why Derrida thinks forgiveness transcends politics. First, pure forgiveness is not instrumental. It is offered wholly for the sake of the other. But in politics forgiveness is always appropriated into the 'service of a finality', such as national reconciliation, which involves the restoration or reaffirmation of a shared norm and a normative order (Derrida 2001, 31-32). Second, pure forgiveness is unconditional. When it becomes part of an economy of exchange, it loses its 'gift-like' like character and transformative power. ${ }^{20}$ Third, Derrida seems to think that pure forgiveness must involve an unmediated relation between the forgiver and the one who is forgiven: 'Pure forgiveness engages two singularities (guilty and victim). As soon as a third party intervenes [i.e. the law] one can again speak of amnesty, reconciliation, reparation, etc. but certainly not of pure forgiveness in the strict sense' (Derrida 2001, 42). On this account, forgiveness is unavoidably ideological to the extent that is political.

\footnotetext{
${ }^{20}$ Here I think Derrida is wrong. There is no such thing as a gift that does not establish a relation of reciprocity. As Ricoeur $(2004,482)$ points out, even when forgiveness is pure it hopes for something back: to turn an enemy into a friend.
} 
In contrast, Arendt gives at least three reasons why she thinks forgiveness is an inherently political faculty. First, forgiveness presupposes plurality, the presence of equal but distinct others. Like Derrida, Arendt views forgiveness in contrast to the value of sovereignty or self-mastery. It is precisely because in politics we find ourselves in a predicament of nonsovereign freedom that the need for forgiveness arises. She understands forgiveness to be a fundamentally political faculty because forgiveness provides a way of dealing with this predicament without recourse to a juridical morality or the institution of sovereignty. Second, forgiveness shares with political action its initiatory character. As with the exercise of human freedom through action, forgiveness always surprises. It 'does not merely re-act but acts anew and unexpectedly, unconditioned by the act which provoked it' (Arendt 1998, 235). Third, forgiveness has the revelatory quality of action. For Arendt, it is through acting that individuals distinguish themselves or reveal who they are in their singularity. Forgiveness has a similar quality since 'what was done is always forgiven for the sake of who did it' (Arendt 1998, 241). Forgiveness recognises and affirms the singular other while establishing a relationship with her.

Given Arendt and Derrida's fundamental disagreement over the extent to which forgiveness is political, one would expect them to hold very different conceptions of politics. On closer examination, however, there are some surprising similarities between them. The similarities are more evident once we understand their discussion of forgiveness in terms of Lefort's politics/polity distinction. While Derrida thinks that forgiveness is beyond politics (in the ordinary sense of the word), his account of a pure forgiveness is political (in the sense of polity). On the other hand, when Arendt insists on forgiveness being inherently political, she does so in the context of the idealised conception of polity she describes throughout The Human Condition. ${ }^{21}$ Consequently, for both Derrida and Arendt, forgiveness remains at a certain remove from politics since each connects forgiveness to a conception of polity in terms of which politics might be staged.

\footnotetext{
${ }^{21}$ This is an account of 'the political' according to which almost everything we ordinarily take to be politics is described as un- or anti-political. For example, strategic or instrumental action is described as work rather than action and is thus said to express an anti-political mentality.
} 
That Derrida's notion of a pure forgiveness is political in the sense of polity becomes clear when he tries to explain how the ethical imperative of an unconditional forgiveness might inflect ordinary politics. In terms of recognising the impossibility of forgiveness, Derrida writes:

But I would make of this trans-political principle a political principle, a political rule or position taking: it is necessary also in politics to respect the secret, that which exceeds the political or that which is no longer in the juridical domain. This is what I would call the 'democracy to come'.

(Derrida 2001, 55)

In an interview, Derrida $(2002,180)$ remarks that after he gave a lecture around the idea of 'democracy to come' a student said to him 'What you call democracy is what Arendt calls republic in order to place it in opposition to democracy' to which Derrida responds 'Why not?'. Both Arendt and Derrida are interested in conceptualising the possibility of the radically new in politics, which is not already presupposed within an existing order of expectations. The invocation of polity as an ideal community in which all are equal yet each is recognised in her singularity provides a basis in terms of which to conceptualise this possibility.

But at least two significant differences remain. First, in Derrida the idea of a polity that transcends politics is presented in eschatological terms as democracy to come. In the interview mentioned above, Derrida $(2002,182)$ writes 'what I have said elsewhere about the coming, the event, the "come here" - of différance and the deconstruction of presence, is where I would begin to try to articulate a thinking of the political' (182). Importantly, Derrida does not understand the 'to come' of democracy in teleological terms, as a regulative idea or future end, that the present instantiation of political community might be made to approximate. Rather, as Simon Critchley (2000, 463) puts it, 'the experience of justice as the here and now is the à venir [to come] of democracy...the temporality of democracy is advent, it is futural, but it is arrival happening now, it happens...as the messianic now blasting through the continuum of the present' (see also Fritsch 2002). 
There is an affinity here with Arendt's conception of polity (or what Derrida calls 'the political' above) in that both thinkers understand polity as a certain potentiality that transcends any existing order of expectations as contained, for instance, in a legal order. Yet there is also a subtle difference in that, for Arendt, polity is not conceived in terms of an ethical injunction that is made on political life from the outside. Rather, it is an extraordinary potential inherent to politics. What she offers in The Human Condition is a protology: an account of politics that is prior to the establishment of institutions, which furnishes a description of the political potential of humans. This protology provides political grounds for forgiveness - the fragility of the intersubjective world and the natality of the other - where liberalism and realism (which disclaim any metaphysical presuppositions) fail to (see Schaap 2005, 109112).

Recognition of the predicament of non-sovereign freedom in which politics is enacted provides the basis for an ethic of care for the intersubjective world that is potentially constituted through politics. But polity, itself, does not take the form of an ethical injunction. This is indicated, for instance, in Arendt's (1998, note 78, 240) effort to find non-moral terms in which to describe forgiveness as 'releasing' or 'dismissing' our transgressor in contrast to Derrida's representation of forgiveness in Levinasian terms of an infinite responsibility to the other (i.e. 'forgiving the unforgivable'). So whereas polity in Derrida that takes the form of an ethical injunction or 'messianic a priori' (Critchley 2000: 458) ${ }^{22}$, in Arendt polity is an ever-present possibility of action in the present.

This points to a second important difference. Arendt sees in the political modes of acting and speaking the potential to disclose an intersubjective world. As such, the disclosure of polity depends on the presence of a plurality of acting and speaking subjects. As Arendt $(1998,199)$ writes, 'wherever

\footnotetext{
${ }^{22}$ Critchley (2000: 458) explains that the messianic a priori describes the structure of intersubjectivity in terms of an asymmetrical obligation that I could never meet, to which I would never be equal.' He goes on to note that Habermas might wonder whether Derrida's emphasis on asymmetry and infinite responsibility would suffer from the ethical overload that Habermas criticises republicanism for. To which, Critchley suggests, Derrida might respond that 'ethics is always - and rightly - an experience of overload' (459). I have explored the disjunction between Arendt's conception of politics and the Levinasian notion of an infinite responsibility in Schaap (2004).
} 
people gather together it is potentially there, but only potentially, not necessarily and not forever.' In contrast, Derrida is suspicious of any kind of symmetrical intersubjectivity (which he equates with reciprocity) since he views this as always involving a violence to or appropriation of the other. Instead, Derrida's conception of polity is conceived in terms of a relation to the other that is predicated on an asymmetrical obligation that could never be met.

If forgiveness remains associated with polity in both Arendt's protology and Derrida's eschatology, how are we to understand the role of forgiveness in politics? Does this mean that forgiveness remains always out of reach? Is it a hopelessly utopian aspiration? One way of putting the question is to consider whether the invocation of polity is utopian or aporetic. If forgiveness is utopian, it suggests that it is without a place in ordinary politics because it remains an empty ideal. If forgiveness is aporetic, it is without a path. As such it remains as a real possibility, albeit one that is not contained within the present system or existing order of expectations (see Rose 1982, 201). ${ }^{23}$ When understood in these terms, Arendt's and Derrida's notions of forgiveness as an extraordinary potential of ordinary politics on the one hand and unassumable ethical injunction that inflects ordinary politics on the other are both intended to articulate 'the possibility of change in each determinate context' (Patton 2004, 32).

The point of drawing the distinction between Arendt's protological and Derrida's eschatological conceptions of polity, then, is not to argue for the priority of one or the other. Rather, it is to show that a politics of reconciliation needs both insofar as it must be look both backward and forward to a protopolitical community. A politics of reconciliation must rely on the invocation both of a counter-factual "we" that is prior to the institution of social contract and to a "we" that is always not yet. In this way, the proto-political concept of reconciliation enables a politics of reconciliation in the present. The invocation of polity (and therefore the possibility of forgiveness) is a way of describing this reference to a quasi-transcendent universal without positing it as a

\footnotetext{
${ }^{23}$ According to Paul Patton $(2004,32)$, the point of Derrida's distinction between the heterogenous orders of the conditional and unconditional is 'to remind us that we are not completely defined by the existing practices that determine our political being'.
} 
regulative idea or claiming its incorporation within a particular historical community. Politics, insofar as it is not just a strategic calculation of selfinterest but an ethical undertaking, consists in negotiating the conflicting demands of law and love, the conditional and the unconditional or the general and the singular with a view to the possibility of more just social relations. For former colonisers and the formerly colonised to engage in this political negotiation in a democratic way is for them to live together, as Johan Van der Walt (2004) describes it, not reconciled but in reconciliation.

\section{References}

Arendt, H. 1998. The Human Condition, second edition. Chicago \& London: University of Chicago Press.

Atria, F. forthcoming. 'Reconciliation and Reconstitution.' In Law, Time and the Politics of Reconciliation, ed. E. Christodoulidis \& S. Veitch.

Aldershot: Ashgate Publishing.

Christodoulidis, E. 2000. 'Truth and Reconciliation' as Risks.' Social and Legal Studies 9(2): 179-204.

Critchley, S. 2000. 'Remarks on Derrida and Habermas.' Constellations 7(4): 457-465.

Dallmayr, F. 1993a. 'Politics and Power: Ricoeur's Political Paradox Revisited.' In Meanings in Texts and Actions: Questioning Paul Ricoeur ed. D. E. Klemm and W. Schweiker. Charlottesville: University Press of Virginia.

Dallmayr, F. 1993b. 'Post-metaphysical Politics: Heidegger and Democracy?' In his The Other Heidegger. Ithaca: Cornell University Press.

Derrida, J. 2001. 'On Forgiveness.' In On Cosmopolitanism and Forgiveness. London \& New York: Routledge.

Diprose, R. 2002. Corporeal Generosity: On Giving with Nietzsche, MerleauPonty and Levinas. Albany: State University of New York Press. 
Flynn, Bernard. 1998. 'Lefort.' In A Companion to Continental Philosophy, ed. S. Critchley \& W Schroeder. Oxford: Blackwell, 484-491.

Fritsch, M. 2002. 'Derrida's Democracy to Come.' Constellations 9(4): 5745597.

Gutmann, A. and D. Thompson. 2000. 'The Moral Foundations of Truth Commissions.' In Truth V. Justice: The Morality of Truth Commissions, ed. R I Rotberg \& D Thompson. Princeton: Princeton University Press.

Habermas, J. 1996. Between Facts and Norms. Cambridge: Polity Press. Janover, M. 2005. 'The Limits of Forgiveness and the Ends of Politics.' Journal of Intercultural Studies 26(3): 221-235.

Kerruish, V. and J. Purdy. 1988. 'He 'look' honest - big white thief.' Law/Text/Culture 4(1): 146-67.

Kolnai, Aurel. 1977. 'Forgiveness.' In Ethics, Value and Reality. London: The Althone Press.

Krog, A. 1998. Country of My Skull. Johannesburg: Random House South Africa.

La Caze, M. forthcoming. 'Between Apology and Forgiveness.' Contemporary Political Theory.

Lefort, C. 1988. Democracy and Political Theory. Cambridge: Polity Press.

Moon, C. 2004. 'Prelapsarian State: Forgiveness and Reconciliation in Transitional Justice.' International Journal for the Semiotics of Law 17: 185-97.

Moran, Anthony (1998) 'Aboriginal Reconciliation: Transformations in Settler Nationalism.' Melbourne Journal of Politics 25: 101-132.

Muldoon, Paul (2003) 'Reconciliation and Political Legitimacy: The Old Australia and the New South Africa.' Australian Journal of Politics and History 49(2): 182-196.

Murphy, J. 1988. 'Mercy and legal justice.' In J. Murphy \& J. Hampton, Forgiveness and Mercy. Cambridge: Cambridge University Press. 
Norval, A. (1998) 'Memory Identity and the (Im)possibility of Reconciliation:

The Work of the Truth and Reconciliation Commission in South Africa.' Constellations 5(2): 250-265.

Patton, P. 2001. 'Reconciliation, Aboriginal Rights and Constitutional Paradox in Australia.' The Australian Feminist Law Journal 15(1): 25-40.

Patton, P. 2004. 'Politics.' In Understanding Derrida, ed. J. Reynolds \& J. Roffe. New York \& London: Continuum.

Perrin, S \& Veitch, S. (1998) 'The Promise of Reconciliation.' In Law, Text, Culture 4(1): 225-32.

Phillips, M. 2005. 'Aboriginal Reconciliation as Religious Politics:

Secularisation in Australia.' Australian Journal of Political Science 40(1): $111-24$.

Ricouer, P. 1965. 'The Political Paradox.' In History and Truth. Evanston: North Western University Press.

Ricoeur, P. 2004. Memory, History, Forgetting. Chicago \& London: University of Chicago Press.

Rose, G. 1982. The Broken Middle: Out of Our Ancient Society. Oxford: Blackwell.

Rose, G. 1996. Mourning Becomes the Law: Philosophy and Representation. Cambridge: Cambridge University Press.

Rousseau, J.J. [1762] 1997. 'The Social Contract.' In The Social Contract and Other Later Political Writings, ed. V. Gourevitch. Cambridge: Cambridge University Press.

Schaap, A. 2004. 'Assuming responsibility in the hope of reconciliation.' borderlands e-journal 3(1).

Schaap, A. 2005. Political Reconciliation. London \& New York: Routledge.

Schaap, A. 2006. 'Agonism in Divided Societies.' Philosophy and Social Criticism 32(2). 
Schmitt, C. 1985. 'Political theology.' In Political Theology: Four Chapters on the Concept of Sovereignty, trans. George Schwab. Cambridge, MA: MIT Press.

Short, D. 2005. 'Reconciliation and the Problem of Internal Colonialism.' Journal of Intercultural Studies 26(3): 267-282.

Van Roermund, B. 1996. 'The Concept of Representation in a Parliamentary Democracy.' Current Legal Theory 14(1): 31-52.

Van Roermund, B. 2001. 'The Grammar of Reconciliation: Rubbing Off and Rubbing On.' In Lethe's Law: Justice, Law and Ethics in Reconciliation, ed. E. Christodoulidis \& S. Veitch. Oxford: Hart Publishing.

Van Roermund, B. 2004. 'Never Again: Time Frames in Anamnesis and Reconciliation.' Paper presented at the fourth colloquium on Time, Law and Reconciliation. University of Johannesburg, December 2004.

Van der Walt, J. 2003. 'Psyche and Sacrifice: an Essay on the Time and Timing of Reconciliation.' Journal of South African Law 4: 635-651.

Verdeja, E. 2004. 'Derrida and the Impossibility of Forgiveness.'

Contemporary Political Theory 3(1): 23-47. 


\section{University Library}

\section{- M I N E R VA A gateway to Melbourne's research publications}

Minerva Access is the Institutional Repository of The University of Melbourne

Author/s:

Schaap, Andrew

Title:

The proto-politics of reconciliation: Lefort and the aporia of forgiveness in Arendt and Derrida

Date:

2006

Citation:

Schaap, A. (2006). The proto-politics of reconciliation: Lefort and the aporia of forgiveness in Arendt and Derrida. Australian Journal of Political Science, 41(4).

Persistent Link:

http://hdl.handle.net/11343/33406

File Description:

The proto-politics of reconciliation: Lefort and the aporia of forgiveness in Arendt and Derrida 


\section{University Library}

\section{- M M N E R VA A gateway to Melbourne's research publications}

Minerva Access is the Institutional Repository of The University of Melbourne

Author/s:

Schaap, A

Title:

The proto-politics of reconciliation: Lefort and the aporia of forgiveness in Arendt and Derrida

Date:

2006-12-01

Citation:

Schaap, A. (2006). The proto-politics of reconciliation: Lefort and the aporia of forgiveness in Arendt and Derrida. AUSTRALIAN JOURNAL OF POLITICAL SCIENCE, 41 (4), pp.615-630. https://doi.org/10.1080/10361140600959817.

Persistent Link:

http://hdl.handle.net/11343/28592 